Adam Mickiewicz University in Poznań, Poland

\title{
The presidency as a task. The image of Poland's presidency of the Council of the European Union in selected Polish weekly magazines
}

\section{Introduction}

\begin{abstract}
lthough the presidency of the Council of the European Union is exer-

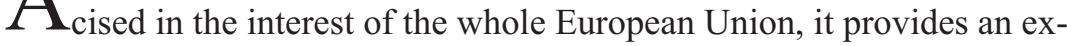
cellent opportunity also to promote national interests and the image of the presiding country (Albrycht, 2009) 'amplifying' its message (Bengtsson, Elgström \& Tallberg, 2004, p. 330). The tasks of national promotion on the occasion of Poland's presidency were extensively analyzed in the Program of Poland's preparation for assuming and administering the presidency of the EU Council adopted by the Council of Ministers on January 13,2009 . It mentioned the significant role played by communications addressed at external groups, that is international circles, in particular the institutions and societies of the countries holding the presidency before and after Poland, as well as internal groups, that is central administration and local government units, society, professionals and experts, media and Poles living abroad. The Program ... placed particular stress on the role of the media as the primary target group for whom special materials would be prepared and published on the presidency's website (Urząd Komitetu Integracji Europejskiej, 2009, pp. 49-55).

The significance of media coverage of Union topics is best evidenced by the fact that the ability to cooperate with the media is among the crucial measures of assessing the efficiency of the presidency in terms of its communication and representation (Młynarski, 2011, pp. 201-248). The everyday work of EU institutions is not a part of citizens' common experience, therefore the information society obtains on politics, including European politics, comes from the media. The significance of the presidency for Poland, being a new member state, the promotional role of the institution of the presidency as perceived by government structures, and the fundamental role of the media in creating the state's image make the issue of
\end{abstract}


the presidency's representation in the media a significant research issue. Regardless of the intentions of political actors, the media observe the political system in line with their own criteria of importance and the logic of presentation, and they create a particular vision of reality, selecting topics, choosing a defined perspective to present issues, and selecting the actors that constitute a part of the message. These are additional aspects that make the study into the image of the presidency in the media an important and interesting research issue. The objective of this paper is to analyze media coverage of Poland and the European Union as regards the Polish presidency of the Council of the European Union on the basis of two periodicals with pro-government sentiments, in the analyzed time frame. The task of this paper is to answer the question of the mechanisms creating the image of Poland, Europe/European Union, and the Polish presidency. Additionally, the paper shall also identify the mechanisms for creating support for the governmental vision of Poland, the European Union and Polish presidency.

\section{Theoretical and methodological considerations}

The theoretical assumptions of this paper are based on the analytical ideas and categories developed by critical discourse analysis. Discourse is comprehended as a specific manner of linguistic coding of events, objects, persons and situations which is strictly related to context (Wodak, 2008, pp. 4-6). Discourse is a kind of social practice which on the one hand shapes social reality and on the other hand is influenced by it (Fairclough \& Wodak, 1997, p. 55). The constitutive character of discourse is expressed by its ability to generate the identity of its actors, their mutual relations and knowledge about the world. For example, the discourse on the European Union is based on specific constructions of individual and collective identities (of state and its raison d'état, ruling and opposition political parties, institutions, politicians, etc.), the representations of their mutual relations, and a defined vision of the world generated by these actors and their relations.

Using language in context is related to the power relations in a given society. Various entities seek to achieve hegemony, and thus create a situation where the subordination to power results from sharing a common vision of reality. This vision is embedded in discourse and results from the selection of defined strategies of representation, thus having an ideologi- 
cal character (Richardson 2007, p. 38). Therefore, a researcher's objective is to critique this, in the sense of revealing the manners in which the world is linguistically constructed so that it contributes to the reproduction of power relations. In modern societies the media play a specific role in the construction of the vision of the world, and hence in the construction of power relations. In the hermeneutical perspective, journalists are a kind of an interpretative community that develops the strategies for the collective comprehension of the world (Zelizer, 2009, p. 182). Media representation of the world can be understood as naturalization strategies, making this world obvious and irrefutable.

This paper treats the media as a political actor, thereby implying the existence of a subject that undertakes observable actions and is sufficiently unified to implement coherent discursive strategies (Page 1996, p. 20). These strategies are understood as more or less intentional plans to apply practices to achieve social, political, psychological or linguistic goals (Reisigl \& Wodak, 2001, p. 44). It is particularly justifiable to approach the media as political actors in the Polish case, where acute political polarization is reinforced by the media, and various political factions are frequently surrounded not only by a network of social organizations but also media organizations that openly support them (Bobrowska, 2007). The paper aims to analyze the discursive ways of constructing the Polish presidency in the selected two government-friendly weeklies, Polityka and Wprost. The paper shall apply selected analytical tools developed by critical discourse analysis in its discourse-historical version, and in particular the concepts of discursive strategies suggested by Ruth Wodak and Martin Reisigl. The latter writes that a useful heuristic instrument in examining political discourse is provided by an analysis of the ways of nominalization - that is constructing social actors, predications - attributing specific features to them, an argumentation that either justifies or refutes statements that include examples of nominalization and predication, and, eventually, perspectivization, which concerns the viewpoint of a text's author (Reisigl, 2008, pp. 99-100).

The analytical network developed by the discursive-historical version of the critical analysis of discourse will facilitate the systematic examination of a corpus of texts in order to answer the question of the image of the Polish presidency in the selected media. This general question is divided into two detailed ones. The first one concerns the representation of Poland in the discourse on the presidency, while the second one concerns the representation of Europe/European Union in the same discourse. A detailed 
analysis of mechanisms applied to represent the Polish presidency in the European Union will indicate how the main entities in the discourse were named and defined, as well as how assessment and argumentation were carried out. The analysis of the image of Poland shall focus on the forecasts and expectations made of the presidency, representation of the government, the opposition and their mutual relations, the role of the Polish presidency and its overall assessment. The examination of the image of Europe shall, in turn, involve an analysis of how the status quo is defined (What is the EU? What is its present condition?), the normative image of the EU (What should the EU be?) and, finally, the assessment of the Polish presidency by the EU and European countries. Additionally, the paper shall also indicate the mechanisms for building support for the government and its vision of Poland, Europe/EU and the Polish presidency. This will be aided by an analysis of the ways of representing social actors, manners of quoting, presence of political actors in both periodicals and the congruence of perspectives of the visions of Poland, Europe/EU and the Polish presidency.

The research sample comprises press materials published by two nationwide weeklies of Polityka and Wprost. The sales of printed issues of both periodicals ranked high in 2011 as Polityka sold approximately 133,000 issues and Wprost 100,000. Both magazines supported the ruling party in the conflict between the largest parties - Civic Platform (PO) and Law and Justice (PiS) which was the main issue in Poland after 2005. Even before the parliamentary elections in 2007 Polityka cheered Donald Tusk on with a front page slogan "Tusk, you have to!" while Wprost editor-in-chief at the time, Tomasz Lis, strongly criticized PiS in his numerous public announcements (Janicki \& Władyka, 2007; Lis, 2007). Both weeklies are decidedly pro-European and treat Poland's membership of the EU and strong integration as the Polish raison d'état. Such empirical foundations provide an excellent insight into the mechanisms of building support for the governmental perspective adopted as the editorial board's own outlook. The sample was selected in two stages. Out of all the texts published between July 2011 and January 2012, those including the key word of presidency were selected. Next, this corpus of texts was limited to those that approached the issue of the presidency solely in the traditional political perspective, related either to domestic or international relations. In this way, articles on, say, culinary matters or interviews about cultural events were eliminated, as were those where the presidency was only briefly mentioned. 


\section{The analysis}

Socio-political actors in two weekly magazines

The importance of the Polish presidency of the EU Council and the approach taken by the periodicals is evidenced by the selection of authors and interlocutors. In Polityka, the texts announcing the beginning and concluding of the presidency were written by Marek Ostrowski, who deals with international matters, Jerzy Baczyński - the editor-in-chief, Paweł Świeboda - the president of the pro-European foundation demosEuropa - Center for European Strategy and a columnist in the Gazeta Wyborcza daily, and Adam Krzemiński, who specializes in German issues. The texts published by Wprost were written by Magdalena Środa - a columnist of the magazine and Jacek Pawlicki - a journalist from Gazeta Wyborcza who specializes in European issues. Interestingly, in both cases we are dealing with external journalists who are treated as EU experts and are associated with another periodical. The objective and expert style dominating in the articles was further maintained by the selection of interviewees - state or EU officials and experts, such as Commissioner for Financial Programming and the Budget Janusz Lewandowski, Secretary of State for European Affairs, responsible for the Polish presidency in the Ministry of Foreign Affairs, Mikołaj Dowgielewicz, and President of the Institute of Public Affairs Jacek Kucharczyk. Paweł Świeboda, the author of a text published in Polityka acted as an interviewee in Wprost.

In an analysis of media discourse the attribution of a text plays a significant role, as well as the attribution within the text, or the manner in which the statements of other people are introduced in a given text (Piekot, 2006, pp. 186-198). Due to the specific nature of journalistic genres examined (current affairs articles, editorials, interviews) the number of quotes analyzed in the corpus is definitely smaller than in the case of press releases (Wojtak, 2004). The following speakers were quoted directly and indirectly: Donald Tusk, Konrad Niklewicz, Radosław Sikorski, academics, left-wing intellectuals, experts (i.e. Michael Porter from Harvard Business School, Jürgen Habermas, Timothy Garton-Ash, and Daniel Cohn-Bendit), as well as foreign and EU politicians (i.e. Jean Claude-Junckner - Luxembourg Prime Minster and Martin Schulz - the leader of the Socialist Group in the European Parliament). The quotes from government politicians usually illustrated the line of the periodical or individual actors, sometimes 
assuming the character of overt support for a given standpoint: "Actually, it is Sikorski who is right..." (Krzemiński, 2011b, p. 12). Characteristically, in the case of PO politicians, not only were the quotes affirmative, but the acts of speech were labeled in a way that constructed their authors' identities as men of state who were equal to their European partners. This can be exemplified by introducing a fragment of Donald Tusk's statement with the verb "admonished" when referring to the possibility of European states opting for different speeds (Pawlicki, 2012, p. 86). The notion of a "historical statement", describing a fragment of Radosław Sikorski's speech in Berlin of November 28, 2011, was decidedly positively marked (Krzemiński, 2011b, p. 12).

When discussing domestic issues and the internal situation in Poland, the discourse on the presidency typically used the metonymic reference of "Poland" rather than "Warsaw", which was much less frequent. The name of the country was thus used to refer to the activity of the government and its representatives, and frequently stood for the whole community. In the latter case, the verb in third person singular was used together with the verb in the first person plural (Kucharczyk 2012, p. 92). Such representation served the purpose of generating a common identity and interest and suspended considerations on internal diversification. Regardless of strategic aspects, such mechanisms are typically used when writing about the Union's policy, or broader international policy (Oberhuber, Bärenreuter, Krzyzanowski, Schönbauer \& Wodak, 2005, pp. 227-271). The role of Poland was constructed by means of anthropomorphization, where the country was presented as an actor that was supposed to take concrete steps or that had already done so. One could therefore read that Poland "showed," "obtained," or "doesn't like" something (Kucharczyk, 2012, p. 92; Środa, 2011, p. 31). Other frequently mentioned internal actors included D. Tusk, R. Sikorski, J. Rostowski, and S. Niesiołowski. They were represented as active or persuasive actors whose words were quoted in an affirmative manner. Donald Tusk was described as a "European modernizer" (Łakomski, 2011, p. 28) or "reasonable politician" and Radosław Sikorski as author of the most important speech that had been anticipated from the beginning of the presidency (Krzemiński, 2011b, p. 12). Government politicians were not criticized but rather encouraged to be even more active. The articles used various arguments to encourage and persuade them to become more active in Europe, for instance: "the Prime Minister needs to be seen more. In Europe he enjoys an image of a reasonable politician you can do business with, but hardly anybody can say more 
about him. It is not a great secret that the Prime Minister does not like to speak in public when abroad" (Ostrowski \& Świeboda, 2011, p. 52).

Another significant instrument involved functionalization, which, according to Theo van Leeuwen, is about representing social actors by means of the functions they perform (Van Leeuven, 2008, p. 42). The following quotes are excellent examples: "The idea that Minister of Finance Jacek Rostowski as a representative of the presidency could sit at one table with the eurogroup (the 17 finance ministers from the eurozone countries) without the right to vote had to be abandoned" (Pawlicki, 2012, p. 86); "If we were to show the actors of Polish political stage in late 2011, the picture could look like this: in the lead there is Prime Minister Donald Tusk holding a banner 'Europe, reforms' who is being pulled back by Deputy Prime Minister Waldemar Pawlak, clutching at his jacket flaps. Completely apart, in Rejtan's pose ${ }^{1}$ but standing up, he cannot be kneeling, after all, there is steadfast Jarosław Kaczyński with a banner 'I won’t allow it!', but in the background quite a number of fleeing activists can be seen. In the middle, Leszek Miller and Janusz Palikot are fighting over a cloth turned gray, reading 'The Left Wing"' (Paradowska, 2011b, p. 34).

The second fragment reveals the mechanisms of representation of opposition political actors, in particular the most frequently featured Jarosław Kaczyński and PiS. The deprecating and satirical tone ("steadfast", "cloth turned gray"), reference to Polish historical context (Rejtan), or ridiculing of opposition demands (Krzemiński, 2011b, p. 12) and belittling their importance ("callithump") (Baczyński, 2011, p. 12) sometimes gave way to psychologization or psychiatrization mechanisms ("Kaczyński overwhelmed by obsessions") (Łakomski, 2011, p. 28). Additionally, tradition was identified with utter anachronism, allowing comparisons of J. Kaczyński to an "antediluvian fossil" (Krzemiński, 2011b, p. 12). PiS was subjected to direct criticism (Materna, 2011, p. 9) and polemicized with as regards its slogans, earlier statements and opinions (Krzemiński, 2011 b, p. 12). In general, the largest opposition party and its leader were alternately presented as a threat to the Polish presidency, or utterly anachronistic, anti-European political actors who are incapable of recognizing reality.

1 Tadeusz Rejtan tried to prevent the legalization of the first partition of Poland in 1773. A 1866 painting by Jan Matejko pictures Rejtan lying on the threshold of a chamber trying to prevent the members of parliament from entering it and signing the partition document [translator's note]. 
The representation of Poland's internal situation was not a particularly important element of opinions concerning the presidency, and it was referred to rarely and indirectly. There were three predominant subjects: the economic situation of Poland, the diagnosis of social support for the EU, and the parliamentary elections to be held during the presidency. In economic terms, Poland was presented as an outstanding country, handling the crisis well, and a strong and valuable EU member. In social terms, the Euro-enthusiasm of society was significant, as emphasized by journalists and their interviewees from the world of Polish and Union policy ("enormous support for European idea") (Dowgielewicz, 2011, p. 90). The elections, an important political parameter at the time of the presidency, were treated as a threat, mainly due to the possibility of the opposition negatively exploiting European issues, or the stronger resonance of party struggle in Poland in the forum of EU institutions, due to the presidency. The issue raised by the opposition, that is the opportunity for the government to exploit European issues for election purposes, was not taken into consideration. A strategy of reversing this argument was also applied. In contrast to the printed media that opposed the cabinet of Donald Tusk, here the presidency was presented as an event that does not help the government, but on the contrary, as one that could generate election problems (Paradowska, 2011a, p. 15).

The Polish presidency of the EU Council - the expectations and hopes

In the case of both weeklies, the timeframe had a very strong influence on the way of handling the topic of the presidency, dividing the event into an introductory and final stage. From the point of view of the subjects of discourse, this means that most attention was paid to the expectations and hopes related to assuming the presidency on the one hand, and to conclusions and assessments on the other. The main assumption underlying both types of articles was the belief that the presidency was highly important for Poland, while noticing its limited competences on the European level and restricted duration. For instance, M. Dowgielewicz said in an interview that "it is important to have realistic expectations of the presidency. It is only 184 days long so we can initiate some processes" (Dowgielewicz, 2011, p. 90). The editor-in-chief of Polityka moderated the strength of his opinions using an indefinite pronoun 'some' when describing the power of the presidency ("This is some kind of power that can be used in a variety of 
ways") and his expectations ("I do not have some great expectations of the presidency") (Baczyński, 2011, p. 12). At the same time, however, the presidency was also presented as a "national project that is strategic for the Polish state" and "the largest logistic operation in the history of the Polish administration so far" (Ostrowski \& Świeboda, 2011, p. 52). Its significance was further emphasized by the identity-forming function of the presidency, which was expected to transform the identity of the state, making it a rightful EU member. The analysts of EU discourse have frequently indicated that the EU topos was presented as a national test (Krzyżanowski, 2008, p. 290; Żuk, 2010, pp. 106-107). The same thinking characterized the considerations on the presidency. The issue of mobilization, hopes for the future, fear of failure and shame in such a case are all clear indicators that the presidency was perceived in terms of a conceptual field strictly related to a task, exam or test to officially confirm the new identity.

The part of the presidency discourse that referred to the future used deontic modality to express the obligation, duty as well as the speaker's expectations (Grzegorczykowa, 2001, p. 133). Journalists and experts formulated statements characterized by this type of modality ("Poland needs to build coalitions carefully," "Poland should decline this term for all cases") (Ostrowski \& Świeboda, 2011, p. 52), while Minister Dowgielewicz formulated assertions and declarations: "we will initiate," "we will dismantle," "we will try" (Dowgielewicz, 2011, p. 90). The main expectations expressed by journalists and experts covered, among other things, exercising the presidency in an active and dynamic manner that influences the European agenda, construing a meaningful EU narrative that would be capable of triggering a pro-integrative stimulus for a stagnant Europe, starting a debate on a new European solidarity, countering the division into a two-pace Europe, and Poland's commitment to the neighborhood policy in the South (Ostrowski \& Świeboda, 2011, p. 52). In a similar way, Dowgielewicz addressed the issue of energy, the good will of Poland as well as the congruity of Poland's interests with the interests of the EU. Not unlike journalists and experts, apart from listing Polish priorities, the minister stressed the rhetorical and symbolic meaning of the presidency: "First and foremost, we are going to try and change the sentiments in Europe that are daunted by the crisis to make them more optimistic" (ibidem).

In terms of expectations and promises, the discourse on the Polish presidency was based on the enumeration of resources that were to ensure the appropriate performance of the tasks on the one hand and the rhetoric 
of shame on the other. The editor-in-chief of Polityka indicated the following assets: the Euro-enthusiasm of Polish society, excellent relations with Germany - a crucial EU state, the clear, positive influence of the European Union in Poland, and, finally, the pro-European government seeking the sources of welfare and prosperity in close integration. Characteristically, the above list was accompanied by the following statement: "Without puffing ourselves up like a peacock, we do have a few unusual strengths" (Baczyński, 2011, p. 12). By making reference to a famous phrase by Juliusz Słowacki, ${ }^{2}$ the author distanced himself from language prone to exaggerating Poland's merits, in particular historical merits, frequently employed by the right wing to justify its demands towards foreign entities. The count of Polish assets was also based on referring to the topos of national uniqueness, national history and pragmatism. Explaining the role the Polish presidency could play, Janusz Lewandowski said "We, Poles, know the price of freedom. Being in the EU we can take from it by the handful, whether this means money or all the other freedoms and benefits, reciprocating with our positivism and optimism in sharing the responsibility for getting the Union out of the present crisis" (Lewandowski, 2011b, p. 92). This statement applies several important strategies. Firstly, it uses the topos of national uniqueness and national history, which explains Polish enthusiasm towards the EU. Secondly, it establishes a relation of equivalence between Poland and the EU, where each party is both a donor and beneficiary. Thirdly, the assets are listed in a way allowing the economically weaker Poland to make a valuable offer of a cultural and symbolic rather than financial nature, which is a typical compensation strategy of peripheral countries with a different economic capacity from the center.

\section{The rhetoric of shame}

The existing analyses show that rhetorical strategies based on shame and fear are particularly frequent in the discourse on European matters (Czyżewski, 2006, p. 127; Horolets, 2006, pp. 225-266). They can be approached as the indicators of the sense of belonging to a normative community constructed by the journalist (the community of the EU in this

2 Juliusz Słowacki (1809-1849) - a Polish romantic poet, who sarcastically described Poland as a "Peacock among nations" in Agamemnon's Tomb [translator's note]. 
case), where shame is generated when community rules are infringed. Fear emerges in response to a structure that is treated as an 'alien' one. Tomasz Zarycki observes that the shame of the symbolic elite (such as journalists) can result from a specific social stratification in peripheral countries, which is based on the relation to the 'center' and its culture. This has to result in a tension between the center-oriented portion of the elite and its other members. Additionally, where a community is traditional, in a sense defined as 'backwardness' or 'parochialism', one can declare being ashamed of one's own society (Zarycki, 2009, p. 153).

In the discourse on the presidency the rhetoric of shame referred not only to current shame, resulting from the differences perceived between Poland and European standards, but also to potential shame that could emerge in case of mistakes or improprieties in the course of the presidency. Journalistic discourse on the presidency referred to this notion and - indicating the disparities between the desired and actual states - it defined the standards of the sense of shame. Thus, the rhetoric of shame had at least two functions. Firstly, it served the purpose of abashment, in order to force state authorities to take action, or to mobilize them right before the beginning of the presidency. For instance, Magdalena Środa wrote about the discord between the priorities of the Polish presidency, in particular that of openness, and the closed nature of Polish society. She also constructed a shameful contrast between the 'old' European states, where equality is an important value, and Poland, where "equality is not of particular significance" (Środa, 2011, p. 31).

The attitudes towards the presidency of Poland, which were reconstructed post factum, also expressed the fear of shame that could result from the presidency: "Before, we prayed for a quiet presidency, for not spoiling anything and staying clear of mishaps" (Kucharczyk, 2012, p. 92); "At the beginning of the presidency in July 2011, I was afraid of a Polish mess" (Pawlicki, 2012, p. 86). Fear also emerged in the context of the opposing right wing, for instance in relation to the behavior of MEPs from PiS at the time of the presidency inauguration in the European Parliament and their reaction to the speech of Donald Tusk (Materna, 2011). The rhetoric of shame defined the standards of the appropriate way of thinking and acting in response to the expectations and reactions of European countries and the whole EU. This is most expressively exemplified by the following statement by Jerzy Baczyński: "Poles happen to have a certain natural skill to invoke history, symbols, faith, or even pathos, and they should not be ashamed of that" (Baczyński, 2011, p. 12). 
While Polityka treated references to history and the past made by right-wing politicians as an expression of anachronism, in the case of Polish activity in the course of the presidency they were defined as a justified means to construe the message. Behaviors stigmatized as shameful were also addressed by the Government Plenipotentiary M. Dowgielewicz calling for the opposition to show restraint (Dowgielewicz, 2011). The same mechanism was also applied in the directive statements about the necessity of cautious operating in the EU forum, so as to avoid waking the stereotypes about Poland (Ostrowski \& Świeboda, 2011).

The construction of shame was possible due to three assumptions that were noticeable in the discourse. Firstly, there was an assumption that there exists a set of values and standards that are identified with Europe or the EU, which are different from Poland's. The Poland-Europe/EU relation was built by means of a better-worse, active-passive, knowing-learning dichotomy rooted in the post-colonial thinking. For instance, Janusz Lewandowski referred to Central and Eastern European states as "Eastern wilderness" or "provincial cousins carrying bundles" (Lewandowski, 2011a, p. 13), while A. Krzemiński talked about the "steppe" (A. Krzemiński, 2011b, p. 12). Secondly, the EU was acknowledged as a significant reference system that Poland can and should be compared to incessantly. This was indicated by the numerous references to current and potential assessments by Europe/EU. The title of one of the articles is quite typical here: "How are we going to be associated in Europe?" (Zespół "Polityki", 2011). Such questions and concerns were formulated both by journalists and politicians. Thirdly, the inequality of this relation was embodied by an image of the presidency perceived as a task to be assessed by European countries upon its completion. Within the framework of a hierarchically described relation, Europe "gave," "transferred," "provided an opportunity," "forced us to make great changes," while Poland was pictured as a passive recipient of a wide range of various goods, and European integration was not a product of active behavior and efforts but a phenomenon that has "happened" to Poland (Ostrowski, 2012, p. 46).

\section{The image of Europe}

The vision of an appropriately exercised presidency and the arguments that accompanied this vision were strictly related to the picture of a future Europe resulting from a successful presidency. The starting point for a fu- 
ture status quo was provided by a diagnosis of the current situation and addressing the problems the presidency should solve. Additionally, references were made to European history and the normative assumptions of what the EU had been at its beginning. The Poland-Europe/EU relations were a separate element. The current picture of the EU approximated the intergovernmentalist concept where EU institutions are treated as an outcome of rational decisions of states aiming to resolve problems (Wiener \& Diez, 2004, p. 8). There were thus mentions of sluggish EU institutions that need to align individual interests with the interests of the EU as a whole, and different interests of states that need to be agreed by EU institutions. This vision of Europe was not far from the liberal perspective where the multitude of interests is perceived as a natural order of things following from the plurality of entities involved. Referring to historical origins of the EU, Janusz Lewandowski recalled two symbolic names of particular importance for liberal thinking: "Thanks to the Union, Europe is the only continent that left the state of nature behind. ... we escaped Hobbes and Locke. [We escaped] towards the pragmatic cooperation of nations respectful of common institutions and principles" (Lewandowski, $2011 \mathrm{a}$, p. 13). Common interests were presented as a project or perspective of international relations generated by their actors within the framework of EU institutions rather than a natural element of identity. This is the context in which to consider such statements as "Do not be offended by differences" or "We need to be aware of all dissimilarities and differences and discuss them frankly. Simultaneously, we need to patiently build better understanding of common interests" (Ostrowski, 2012, p. 46). Therefore, differences between states were accommodated, and antagonisms treated as an inherent feature of a multi-stakeholder approach calling for negotiation and efforts to advance towards community. Characteristically, this vision of Europe was instrumentally legitimized as an institutional system that was more efficient in terms of solving global problems than the nation-state (Eriksen \& Fossum, 2004, p. 437). For instance, Jerzy Baczyński wrote that "it is becoming increasingly clear that none of the great problems EU governments are confronted with can be solved on one's own" (Baczyński, 2011, p. 12).

The picture of the EU presented in the comments on the presidency did not describe a state of affairs but a process whose ultimate stage is unknown. At the same time, all the authors emphasized significant changes in the intergovernmental status quo which began after 2005, posing a considerable threat to the EU's functioning as a whole. The following factors 
were listed among the reasons for infringed stability: the erosion of EU legitimization, increasing power of renationalization tendencies, and the economic crisis. The claims of the erosion of legitimization most often employed the following argumentation scheme: the fundamental goal of European integration was to eliminate wars between nation-states; young generations raised in comfortable political and economic conditions deemed this state of affairs as obvious; the result is a lack of energy and ideas that could give meaning to the European project (e.g. Krzemiński 2011a). Given this perspective, authors mentioned "inertia," lack of "energy," "verve," a "great idea" (Lewandowski, 2011a, p. 13; Baczyński, 2011, p. 12; Pawlicki, 2012, p. 86), or a pessimistic "mood" (Dowgielewicz, 2011, p. 90). Another reason for lacking energy and sluggishness was attributed to an excessively expanded institutional structure that tended to regulate too many fields of life, including exaggerated intervention in moral and national matters, which resulted in the alienation of the European elite from society (Świeboda, 2011). Janusz Lewandowski referred to Brussels "interfering" with economic matters. A negative image of an overgrown administration was expressed by using such notions from the language of euroskepticism as "eurocrats," "Brussels," and "European elite" and applied to the Eastern Partnership initiative as well (Lewandowski, 2011a, p. 13; Świeboda, 2011, p. 3, Winiecki, 2011, p. 54). The lack of energy characterizing European societies and institutions was frequently attributed to a personalized Europe or the EU. This is exemplified by a typical sentence, such as: "After the enlargement, the Union has lost verve and vision, it is struggling in political temporariness, trying with increasing difficulty to balance national egoisms" (Baczyński, 2011, p. 12). The EU is presented here as a kind of an organism capable of feeling and reacting in a way humans do, and attributed with certain properties, which is a relatively common technique in the highly metaphorical discourse on Europe (Mussolff, 2004, p. 83).

Another factor responsible for the EU's difficult situation, that is renationalization sentiments, was most frequently represented by means of two negatively charged categories: populism and egoism. The concentration of nation-states on their own interests and their reluctance to take decisions that could increase the scope of common policy were presented as a standard response of states under the crisis conditions: "Today in Europe there are no influential political movements or leaders calling for the limitation of national sovereignty in favor of common institutions" (Baczyński, 2011,p. 12). Such tendencies were pejoratively termed as egoism 
(Krzemiński, 2011a). There also emerged a negative notion of "extreme anti-European parties" (Lewandowski, 2011a, p. 13). Populism was also presented by means of a metaphor of natural elements, as a flood wave (Pawlicki, 2012).

The third and most crucial factor responsible for the destabilization of the intergovernmental status quo was the crisis. The concept of crisis was applied in order to indicate that the situation was extremely difficult or critical. Depending on concrete texts or topics, this concerned the Polish presidency or the situation in the EU. The former is exemplified by the following sentence: "... we happened to exercise our first presidency right in the middle of the greatest crisis in the history of the EU" (Pawlicki, 2012, p. 86), the latter by: "Never before has the Union suffered from a crisis so multidimensional and so profoundly undermining its foundations, including the most important freedoms of Schengen and the single currency" (Lewandowski, 2011a, p. 13). The second example clearly makes a connection between the crisis and the functioning of the entire EU, yet the presidency discourse frequently applied the concepts, narrowing the scope of this phenomenon only to the eurozone, or to the countries with weaker economies. It was observed, for instance, that "Europe is at a turning point. The peripheries are being eaten away by the fire of economic incompetence of recent years and social unrest and rebellion, which is gaining impetus and may get out of control" (Ostrowski \& Świeboda, 2011, p. 52). This last quotation illustrates several aspects. Firstly, it narrows the origin of the crisis situation down to European peripheries. Other texts, however, universalized the crisis. For instance, A. Krzemiński wrote that "the crisis of the euro is the crisis of the entire EU, not just of the eurozone" (Krzemiński, 2011b, p. 12). Secondly, it used the natural metaphor, a fire in this case, that is a violent, uncontrollable and exceptionally harmful phenomenon. Another category of natural catastrophe that provided the source domain for the metaphorization of the crisis was flood. The crisis was represented in terms of a wave flooding one part of Europe after another. There also emerged a metaphor of the crisis being a fever, which followed from treating the UE as an organism: "Despite the first signs of healing, however, the EU continues to be consumed by fever" (Ostrowski, 2012, p. 46). Thirdly, the crisis was treated as a phenomenon resulting in the disturbance of former interstate relations, the EU institutional system and ways of thinking. The crisis apparently put the Union in a situation where a decision had to be made as concerns its further directions under the unpredictable circumstances ("a turning point") (Ostrowski \& Świeboda, 2011, p. 52). 
The discursive construction of the crisis, however, was not an instrument of hyperbolization and served the purpose of legitimizing reformatory ideas, taking a definitely federative direction (Krzemiński 2011a, b). In this approach, the crisis was not a mere dysfunction proving an erroneous construction of the whole, but it was a developmental stage leading to deeper integration. The functionality of the crisis was emphasized by means of historical analogies and references to the dynamics of EU development. Janusz Lewandowski claimed that "the European community has been maturing through crises since its beginnings. Challenges force us to seek common answers. That is how integration has progressed and Europe has grown" and referred to the example of the United States (Lewandowski, 2011a, p. 13). A. Krzemiński also developed the analogies with the US, following R. Sikorski's historical example of the Polish-Lithuanian federation, and Switzerland. The Soviet Union served as a negative point of reference providing an example of a federation based on coercion (Krzemiński, 2011b, p. 12). The sentences of weak modality, using such expressions as "maybe," "possibly," and conditional mood were to express the openness of the process, as well as hopes for greater integration. "Maybe the process of integration will be rapidly pushed forward to some version of a United States of Europe. After all, the Swiss federation also started from an enormous conflict, or a civil war, actually" (Ostrowski, 2012, p. 46). The postulates of a European federation or a Europe based on greater integration were made by journalists as well as politicians and experts (Baczyński 2011, p. 12; Lewandowski, 2011a, p. 13; Pawlicki, 2012, p. 86). The motto of the Polish presidency: "More Europe" was an unambiguous expression of the pro-integration orientation of the government and was frequently recalled in the statements of politicians (Lewandowski, 2011a, p. 13; Dowgielewicz, 2011, p. 90) and experts (Kucharczyk, 2012, p. 92). The titles of the texts published by the two weeklies left no doubts as to the federative sentiments of their editors, as exemplified by "More Europe," "Together wherever possible," and "The Republic of Europe." The encouragement to take steps towards federation was achieved by means of a rhetorical mechanism of envisaging the consequences in the case of a 'black scenario' taking place (Kochan, 2005, p. 99). This was achieved by showing the alternatives between pro-federation decisions and other feasible scenarios that were always marked by a degree of threat. They concerned the position of Europe in the world, the future of the EU and the future of Poland. In the first case, there was indicated a possibility of a strong EU able to play a significant part in the "new global 
pentarchy," instead of its "global marginalization" as an alternative. In the second case, the alternative for the "true federation" was the "collapse of the euro and a return to national egoisms" (Krzemiński, 2011b, p. 12). As regards Poland, the threat of marginalization and squandering the "great success of accessing the Union" was mentioned (Kucharczyk, 2012, p. 92). A. Krzemiński affirmatively quoted Sikorski's comments on the danger of Poland slipping to the East. The journalist constructed the following alternative: "Either Poland becomes a part of the hard core of the EU, co-creating efficient federal structures, or it will slip to the East like Ukraine, towards the political and economic steppe" (Krzemiński, 2011b, p. 12). The orientalism of the negatively charged word 'steppe' was to evoke all Polish fears of degradation and the complexes of belonging to the less developed part of Europe, while expressing a sense of superiority over Poland's eastern neighbor (Janion, 2008).

The federative vision generates questions about the relations of the EU and Poland, primarily as concerns a potential conflict of national and Union interests. For both weeklies, Polish membership of Europe and non-antagonistic relations were utterly unquestionable. For Poland, the EU was to be as equally natural environment and source of emotions as the nation-state. The EU accession marked the end of Polish history in the sense of achieving a status quo ultimately protecting Poland's national interest (Ostrowski, 2012, p. 46). One article made an intertextual reference to an interview by Donald Tusk in Polityka in 2009, where the Prime Minister talked about the close dependence between the economic development and modernization of Poland on the one hand and the degree of European integration on the other. The author of the later text praised the Prime Minister, emphasizing his uniqueness when compared to other European politicians who were distancing themselves from the EU. Another important issue was the instrumental legitimization applied to argue in favor of EU federalization present also in other analyzed publications (Baczyński, 2011, p. 12). The congruity of journalists and politicians thus concerned not only the EU's finalité but also its legitimization.

The assessment of the presidency

In both weeklies we encounter a positive assessment of the event made by the journalists, experts and political interlocutors. Also at the level of assessments, Polityka retained the picture of the presidency as a task writ- 
ing that "Warszawa properly exercised the presidency" (Ostrowski, 2012, p. 46). J. Pawlicki used a similar metaphor assessing the presidency in terms of an "exam passed" (Pawlicki, 2012, p. 86). The success was not presented exclusively as a consequence of Polish efforts. Referring to Donald Tusk in the context of the outcomes of the Polish presidency personalized them thus attributing their achievement to the Prime Minister. It was significant that the journalists formulated their assessments and that both weeklies created the conditions for the evaluation to be made by the politicians and officials who had prepared and supervised the presidency. For instance, the article in Wprost that concluded the Polish exclusively quoted K. Niklewicz, who described the agreement on the patent package, achieved in the course of the Polish presidency, in the following manner: "This is a great success given that the negotiations on the single European patent had taken thirty years" (ibidem, 2011). Poland's paying so much regard to the opinion of the European Union and its entities gave high significance to positive opinions of European politicians. These concerned, for instance, the willingness of Poland to renounce bias (Pawlicki, 2012, p. 86).

The positive evaluation was additionally reinforced by emphasizing a peculiar situation ("a difficult period," "the most difficult presidency in the history of the Union”) (Mielnik, 2012, p. 90; Pawlicki, 2012, p. 86), or the exceptionally critical attitude of EU politicians. The second instrument was applied by Jakub Mielnik counterpointing the words of M. Schulz about Poland ("this has been the best presidency for years") with those about the Czech Republic ("a few years ago he scolded President Klaus in Hradchany") (Mielnik, 2012, p. 90). Apart from making assessments it was also typical to enumerate the achievements of the Polish presidency, frequently using perfective verbs in the past tense: "Poland gained influence on European politics, showed that she is a major player, prepared the Accession Treaty of Croatia, saved the food aid program" (Kucharczyk, 2012, p. 92; Pawlicki, 2012, p. 86). The causal agent named, however, was not only Poland but also the government. In the statements by M. Dowgielewicz there are constructions in the first person plural, for instance "We presented Poland as a country of economic success and the most pro-European state of the Union," "We enforced the summits of the whole Union rather than the meeting of the leaders of euro zone to be held in late October and in December. We managed to reach an agreement on the 'six-pack'..." (Dowgielewicz, 2011, p. 90). Whereas positive assessments prevailed, there were also remarks indicating the problems or shortcomings of the presidency. Yet, even when critical assessments appeared, they 
were formulated in a language emphasizing their positive motivation ("good will," "political intention") or limiting the failures only to respective issues while presenting a positive overall assessment (Pawlicki, 2012, p. 86).

\section{Conclusions}

The presidency of the Council of the European Union is a unique opportunity to promote the presiding country both internally and internationally. In these terms it provides additional arguments to support the legitimization claims of the authorities on a domestic level and in international relations. A particular role in this process is played by the media, which on the one hand offer detailed coverage of presidency events and on the other hand propagate a certain way of representation that results from their political or ideological stance. This is particularly significant in such countries as Poland, where the political stage is strongly polarized and the media support and develop the attitudes of various political entities rather than perform a critical function.

The purpose of this text was to analyze the mechanisms of representation of Poland's presidency by the Polityka and Wprost weeklies, that is the magazines supporting Donald Tusk's government. The fundamental metaphor used in order to construct the picture of the presidency involved a task, or a national test, categories that were hitherto present in the European discourse. The importance of European issues and the political attitude of both weeklies are best evidenced by the selection of the authors, interlocutors and the sources of quotes that expressed the opinions of people responsible for the Polish presidency and taking a decided pro-European approach as experts. The opinions of the government members, or the picture of the government, were represented not only in a positive but even in an affirmative way, unlike the opposition, whose voice was ignored, marginalized or ridiculed. The presidency was presented as a crucial event for Poland, and the activities and interests of the government were identified with national activities and interests. The presidency was assessed decidedly positively, and any mistakes or problems were marginalized and explained by external conditions. The pro-European speech made at the inaugural and closing ceremonies by Donald Tusk was appreciated, as was R. Sikorski's Berlin address, as both perfectly matched the pro-federative approach of both weeklies. In general, the analysis 
demonstrated that the government's approach was congruent with the standpoint of both weeklies in terms of the expectations, the perception of the status of the presidency, the picture of the opposition, the EU vision and the final assessment of the presidency. It is for further studies to examine to what extent the picture of the situation presented was a part of the space of discourse intersubjectively shared with other entities, and to what extent it was a specific attitude of a certain group of the journals of opinion.

\section{References}

Albrycht I. (2009), Aspekt promocyjny polskiej prezydencji [Promotion aspect of Polish presidency], in: Prezydencja w Unii Europejskiej. Analizy i doświadczenia [EU presidency analyses and experiences], ed. K. Szczerski, Wydawnictwo Uniwersytetu Jagiellońskiego, Kraków.

Baczyński J. (2011), Czy porwiemy Europę? [Will we abduct Europe?], "Polityka", July 6.

Bengtsson R., Elgström O., Tallberg J. (2004), Silencer or amplifier? The European Union presidency and the Nordic countries, "Scandinavian Political Studies", vol. 27 , no. 3 .

Bobrowska E. (2007), Obrazowanie spoleczeństwa w mediach. Analiza radiomaryjnego dyskursu [Media depiction of society. Analysis of the Radio Maryja discourse], Wydawnictwo Universitas, Kraków.

Czyżewski M. (2006), Dyskursy pro- $i$ antyeuropejskie. Polaryzacja i praca "pośredniczaca" (Zarys problematyki badawczej) [Pro- anti-European discourses. Polarization and, 'interceding' work. An outline of research area], in: Europa $w$ polskich dyskursach [Europe in Polish discourses], ed. A. Horolets, Wydawnictwo Adam Marszałek, Torun.

Diez T., Wiener A. (2004), Introducing the mosaic of integration theory, in: European Integration Theory, eds. A. Wiener, T. Diez, Oxford University Press, Oxford.

Dowgielewicz M. (2011), Trzymajcie kciuki: rozmowa J. Pawlickiego [Keep your fingers crossed], "Wprost", July 18.

Ericksen E. O., Fossum J. E. (2004), Europe in search of legitimacy: Strategies of legitimation assessed, "International Political Science Review", vol. 25, no. 4.

Fairclough N., Wodak R. (1997), Critical discourse analysis: An overview, in: Discourse studies: A multidisciplinary introduction, ed. T. van Dijk, Sage, London-Thousand Oaks-New Dehli.

Grzegorczykowa R. (2001), Wprowadzenie do semantyki językoznawczej [Introduction to semantics], PWN, Warszawa. 
Horolets A. (2006), Obrazy Europy w polskim dyskursie publicznym [Europe's images in Polish public discourse], Universitas, Kraków.

Janicki M., Władyka W. (2007), Cień wielkiego brata [A Big Brother’s shadow], Warszawa.

Janion M. (2008), Niesamowita Słowiańszczyzna: fantazmaty literatury [Incredible Slavic: Delusions of literature], Wydawnictwo Literackie, Kraków.

Kochan M. (2005), Pojedynek na stowa. Techniki erystyczne w publicznych sporach [Verbal duel. Techniques in public disputes], Wydawnictwo Znak, Kraków.

Krzemiński A. (2011a), Niemieckie zwatpienie [German doubt], "Polityka”, September 14 .

Krzemiński A. (2011b), Rzeczpospolita Europa [Republic Europe], "Polityka”, December 7 .

Krzyżanowski M. (2008), Konstrukcja tożsamości narodowych i europejskich w polskim dyskursie politycznym po 1989 roku: analiza dyskursywno-historyczna [National and European identity construction in Polish political discourse after 1989: discursive and historical analysis], in: Krytyczna analiza dyskursu. Interdyscyplinarne podejście do komunikacji społecznej [Critical analysis of a discourse. Interdisciplinary approach to social communication], eds. A. Duszak, N. Fairclough, Universitas, Kraków, pp. 267-304.

Kucharczyk J. (2012), Więcej Europy w Europie: rozmowa P. Pisery [More Europe in Europe], "Wprost", January 2.

Lewandowski J. (2011a), Może kryzys nam pomoże: rozmowa J. Żakowskiego [Maybe crisis will help us], "Polityka", July 6.

Lewandowski J. (2011b), Pod ostrzałem: rozmowa J. Pawlickiego [Under fire], "Wprost", July 18.

Lis T. (2007), PiS-neyland: felietony publikowane od listopada 2005 do września 2007 [PiS-neyland: columns published between November 2005 and September 2007], Świat Książki, Warszawa.

Łakomski G. (2011), Rok pod żyrandolem [A year under chandelier], "Wprost”, June 4.

Materna K. (2011), Wdzięk, masowość, bezpretensjonalność [Grace, mass, and unpretentiousness], "Wprost", July 11.

Mielnik J. (2012), Do czterech razy sztuka [Fourth time lucky], "Wprost”, January 2.

Młynarski T. (2011), Wyznaczniki efektywności prezydencji w Radzie Unii Europejskiej w świetle reformy Traktatu Lizbońskiego [Indicators of the EU Council presidency's effectiveness according to the Lisbon Treaty reform], in: Prezydencja w Unii Europejskiej. Praktyka i teoria [The EU presidency. Practice and theory], ed. A. Nowak-Far, Szkoła Główna Handlowa - Oficyna Wydawnicza, Warszawa.

Musolff A. (2004), Metaphor and political discourse. Analogical reasoning in debates about Europe, Palgrave, Houndmills-New York. 
Oberhuber F., Bärenreuter Ch., Krzyzanowski M., Schönbauer H., Wodak R. (2005), Debating the European Constitution. On representations of Europe/EU in the press, "Journal of Language and Politics", no. 2.

Ostrowski M. (2012), Razem, gdzie tylko się da [Together, wherever we can], "Polityka”, January 11.

Ostrowski M., Świeboda P. (2011), My, prezydenci [We, the presidents], "Polityka", June 15.

Page B. I. (1996), The mass media as political actors, "PS: Political Science and Politics", vol. 29, no. 1.

Paradowska J. (2011a), Karty w tas [Shifting cards], "Polityka", July 13.

Paradowska J. (2011b), Rok w zawieszeniu [A year in suspension], "Polityka", December 21 .

Pawlicki J. (2012), Prezydencja. Zdany egzamin [Presidency. Passed exam], "Wprost", January 2.

Piekot T. (2006), Dyskurs polskich wiadomości prasowych [Discourse of Polish press news], Universitas, Kraków.

Reisigl M. (2008), Analyzing political rhetoric, in: Qualitative discourse analysis in social sciences, eds. R. Wodak, M. Krzyżanowski, Palgrave, Houndmills-New York.

Reisigl M., Wodak R. (2001), Discourse and discrimination. Rhetorics of racism and anti-Semitism, Routledge, London-New York.

Richardson J. E. (2007), Analyzing newspapers. An approach from Critical Discourse Analysis, Palgrave, Houndmills-New York.

Środa M. (2011), Średniowiecze w unijnych barwach [The Middle Ages in EU color], "Wprost", July 4.

Świeboda P. (2011), Unia wymyśla się na nowo [Union is reinventing itself], "Wprost", September 5.

Urząd Komitetu Integracji Europejskiej (2009), Program przygotowań Rzeczypospolitej Polskiej do objęcia i sprawowania przewodnictwa w Radzie Unii Europejskiej. Dokument przyjęty przez Radę Ministrów w dniu 13 stycznia 2009 r. [Program of the Polish EU presidency accepted by the Polish government on January 13, 2009], Warszawa.

Van Leeuwen T. (2008), Discourse and practice. New tools for critical discourse analysis, Oxford University Press, Oxford.

Winiecki J. (2011), Partnerzy od niechcenia [Casual partners], "Polityka", September 28 .

Wodak R. (2008), Introduction: Discourse studies - Important concepts and terms, in: Qualitative discourse analysis in social sciences, eds. R. Wodak, M. Krzyżanowski, Palgrave, Houndmills-New York.

Wojtak M. (2004), Gatunki prasowe [Press genres], Wydawnictwo UMCS, Lublin. 
Zarycki T. (2009), Peryferie. Nowe ujęcia zależności centro-peryferyjnych [Periphery. New conceptualizations of relations between center and peripheries], Wydawnictwo Scholar, Warszawa.

Zelizer B. (2009), Journalists as interpretive communities, revisited, in: The Routledge Companion to News and Journalism, ed. S. Allan, Routledge, London-New York.

Zespół "Polityki", Jak Europa nas skojarzy? [How we will be perceived by Europe?], "Polityka", June 29.

Żuk G. (2010), Twierdza czy wspólnota? Europa w polskim dyskursie publicznym [Fortress or community? Europe in Polish public discourse], Wydawnictwo UMCS, Lublin.

\begin{abstract}
Despite the fact that it is exercised in the interests of the European Union as a whole, the presidency of the Council of the European Union is also an excellent opportunity to promote national interests and a positive image of the country, acting as an 'amplifier' of the voice of the state. Particular significance should be ascribed to the European and national media, which can support the positive image of a specific country and its government, but can also undermine such an image. The purpose of this paper is to raise the question of the specific mechanisms of constructing the image of Poland, Europe/European Union and the Polish presidency in the national media. The paper also indicates the mechanisms for building support for the vision of the Polish government, the European Union and the Polish presidency. The theoretical foundations of this article are provided by the analytical categories and concepts developed by critical discourse analysis. The article examines how the media represented individual and collective political actors, attributed specific characteristics to them, and used arguments in favor of a particular vision of Poland, the European Union and the Polish presidency of the EU Council.
\end{abstract}


